\title{
A Distinctive New Species of Ouratea (Ochnaceae) from the Jalapão Region, Tocantins, Brazil
}

Author(s): Kikyo Yamamoto, Roberta Gomes Chacon, Carolyn Proença, Taciana B. Cavalcanti, and Dalva Graciano-Ribeiro

Source: Novon: A Journal for Botanical Nomenclature, 18(3):397-404. 2008.

Published By: Missouri Botanical Garden

DOI: http://dx.doi.org/10.3417/2006096

URL: http://www.bioone.org/doi/full/10.3417/2006096

BioOne (www.bioone.org) is a nonprofit, online aggregation of core research in the biological, ecological, and environmental sciences. BioOne provides a sustainable online platform for over 170 journals and books published by nonprofit societies, associations, museums, institutions, and presses.

Your use of this PDF, the BioOne Web site, and all posted and associated content indicates your acceptance of BioOne's Terms of Use, available at www.bioone.org/ page/terms of use.

Usage of BioOne content is strictly limited to personal, educational, and noncommercial use. Commercial inquiries or rights and permissions requests should be directed to the individual publisher as copyright holder. 


\title{
A Distinctive New Species of Ouratea (Ochnaceae) from the Jalapão Region, Tocantins, Brazil
}

\author{
Kikyo Yamamoto \\ Depto. de Botânica, Instituto de Biologia, Universidade Estadual de Campinas, São Paulo, \\ Brazil.kikyo@unicamp.br \\ Roberta Gomes Chacon \\ Jardim Botânico de Brasília, Distrito Federal, Brazil. rgchacon@gmail.com
}

\section{Carolyn Proença}

Depto. de Botânica, Instituto de Ciências Biológicas, Universidade de Brasília, Distrito Federal, Brazil. cproenca@unb.br

\section{Taciana B. Cavalcanti}

Embrapa Recursos Genéticos e Biotecnologia, Brasília, Distrito Federal, Brazil. taciana@cenargen.embrapa.br

\section{Dalva Graciano-Ribeiro}

Depto. de Botânica, Instituto de Ciências Biológicas, Universidade de Brasília,

Distrito Federal, Brazil

\begin{abstract}
Ouratea acicularis R. Chacon \& K. Yamamoto (Ochnaceae), a new species from the recently created Estação Ecológica Serra Geral do Tocantins, Jalapão region, Brazil, is described. Ouratea acicularis appears to be most closely allied to $O$. oleifolia (A. Saint-Hilaire) Engler. Both species share a pubescent indumentum on the young branches, leaf surfaces, inflorescence axes, and outer surface of the flower buds, as well as revolute leaves and acute flower buds. Ouratea acicularis is unique in the genus in its aciculate leaf blade, at least 4 times narrower than in $O$. oleifolia, with a strongly revolute margin that conceals the abaxial leaf surface except for the midrib, as well as its inconspicuous secondary venation and narrower flower buds. Anatomically, O. acicularis differs from other previously studied species of Ouratea Aublet in that the cells of the adaxial epidermis have an hourglass-shaped lumen, pluricellular forked hairs fused at the base, an unusually large cap of fibers and sclereids above the collateral vascular bundles, and in the predominantly 2 -layered chlorenchyma. The stems of $O$. acicularis are noteworthy for the conspicuous secretory cavities of the cortex and secondary xylem, in which fibers and vessel members predominate.
\end{abstract}

Resumo. Este trabalho descreve Ouratea acicularis R. Chacon \& K. Yamamoto (Ochnaceae), espécie nova da recentemente criada Estação Ecológica Serra Geral do Tocantins, Região do Jalapão, Tocantins, Brasil. Ouratea acicularis se assemelha mais a O. oleifolia (A. Saint-Hilaire) Engler. Ambas as espécies apresentam indumento pubescente nos ramos jovens, em ambas as faces foliares, nos eixos da inflorescência e na superfície externa dos botões florais, bem como folhas revolutas e botões florais agudos. Ouratea acicularis é a única espécie do gênero que possui lâminas foliares aciculares, ca. quatro vezes mais estreitas do que em $O$. oleifolia, com margens foliares fortemente revolutas que escondem a face abaxial da folha exceto a nervura mediana, bem como pela venação secundária inconspícua e botões florais mais estreitos. Anatomicamente, O. acicularis difere das outras espécies já estudadas por apresentar células da epiderme adaxial com lúmen em forma de ampulheta, tricomas pluricelulares fundidos na base, uma capa excepcionalmente desenvolvida de fibras e esclereídeos sobre os feixes vasculares colaterais, e clorênquima predominantemente bi-estratificado. Os ramos de $O$. acicularis são dignos de nota pela presença de cavidades secretoras conspícuas no córtex e pelo predomínio das fibras e dos elementos de vaso e xilema secundário.

Key words: Brazil, IUCN Red List, Ochnaceae, Ouratea, South America. 
The Central Brazilian Highlands are in the core area of the cerrado biome, a poorly protected biodiversity hotspot (Mittermeier et al., 1999). The Jalapão region, in eastern Tocantins, is one of the most underpopulated areas of this biome and, until recently, has remained virtually unknown to botanists. The biological importance of this region has been highlighted by several scientific expeditions (Proença et al., 2002; Reis et al., 2002; Scariot et al., 2002), and the Instituto Brasileiro do Meio Ambiente e dos Recursos Naturais Renováveis (IBAMA) has created a biological reserve in the area, the Estação Ecológica Serra Geral do Tocantins (Arruda \& von Behr, 2002), which encompasses the smaller Parque Estadual do Jalapão. The Estação Ecológica Serra Geral do Tocantins constitutes the largest continuous reserve (716,306 ha.) that is entirely within the cerrado biome in Brazil.

Preliminary collections in the Estação Ecológica Serra Geral do Tocantins resulted in six taxa suspected of being new in Asteraceae, Bignoniaceae, Ebenaceae, Ochnaceae, Rutaceae, and Vochysiaceae (Proença et al., 2002), of which the Bignoniaceae has since been described as a new variety (Proença et al., 2007). This paper describes a new species of Ouratea Aublet (Ochnaceae). The new Ouratea was first collected by both James Ratter (E) and Rosana Farias Singer (UB) on the same expedition in 1998; the Ratter specimen at UB was chosen as the holotype because it is a representative collection in mature fruit, which is duplicated at E. Additional sets of material of this species have been collected in the same region during three scientific expeditions in 2001 and 2002 and distributed to Brazilian herbaria in the Distrito Federal, Goiás, and Tocantins.

The Neotropical genus Ouratea, distributed from Central to South America (Engler, 1876), comprises shrubs and trees that grow in lowland or highland forests or savannas, and sometimes in maritime thickets. The genus has a remarkable pseudoapocarpic gynoecium with a gynobasic style and a gynophore that develops, in the ripe fruit, into a reddish carpophore that displays black mericarps derived from fertilized 1-ovulate units (Baum, 1951; Guédès \& Sastre, 1981; Spujt, 1994; Barroso et al., 1999). Ouratea comprises nearly 300 binomials, but the number of valid species is not yet well established. It is important to note that more than $20 \%$ of these names were only recently described in regional floras of northern South America (e.g., Sastre, 1988, 2001; Maguire \& Steyermark, 1989) and Central America (Whitefoord, 1992). This has increased the number of species known in the genus that have been poorly understood because of their limited distribution in undercollected regions. Although species circum- scription in Ouratea is usually difficult as the genus includes many confusing species complexes (Yamamoto, 1989), some endemic species do have outstanding diagnostic features that make them sharply distinct. This appears to be the case of this new species described here.

Ouratea acicularis R. Chacon \& K. Yamamoto, sp. nov. TYPE: Brazil. [Tocantins:] Mun. Mateiros, $53 \mathrm{~km}$ from Ponte Alta on rd. to Mateiros, $10^{\circ} 30^{\prime} \mathrm{S}, 47^{\circ} 11^{\prime} \mathrm{W}, 400 \mathrm{~m}, 16$ Nov. 1998, J. Ratter, S. Bridgewater, J. Fonsêca Filho \& R. Farias 8115 (holotype, UB; isotype, E). Figure 1.

Frutex caespitosus 1-1.5 m; stipulae in foliis juvenilibus persistentes; rami juniores brevissime puberuli, internodiis 2-10 mm; folia erecto-patentia, petiolo brevi crasso suffulta, lamina lineari vel aciculari, $1.6-9 \times 0.1-0.2 \mathrm{~cm}$, chartacea, pungentia, margine forte revoluta, integerrima, supra paullum puberula demum glabra, subtus dense puberula, nervis lateralibus ubique inconspicuis. Panicula thyrsoidea, terminalis vel subterminalis, angusta, puberula, bracteolis persistentibus, pedicellis florum $6-8.5 \mathrm{~mm}$, tenuibus. Alabastrum $4-5 \times 2.5-3 \mathrm{~mm}$, ovoideum, puberulum, apice acutum; sepalis 5 , ca. $6 \times 3 \mathrm{~mm}$, ovatis, caducis; petalis 5 , flavis; staminibus 10, transverse rugulosis; carpidiis 5, gynophoro columnari-cylindrico, apicem versus pentagono. Monades carpicae fertiles oblongae, carpophoro 2.5-5 × 4-7 mm, salmoneo, base angustato, recurvato, sursum expanso apicem versum pyriformi; mericarpia 1 ad 2 , erecta vel obliqua; semen ca. $0.5 \times 0.3 \mathrm{~cm}$, testa membranacea; embryo planoconvexus, hypocotylo perpendiculari, loriformi. A specie simili O. oleifolia (A. Saint-Hilaire) Engler foliis laminis carentibus, linearibus, marginibus revolutis et venis inconspicuis secundariis, $1.6-9 \times 0.1-0.2 \mathrm{~cm}$ differt.

Shrub 1-1.5 m tall, caespitose, probably a hemicryptophyte; stems erect or sometimes decumbent in fruiting plants, branches cylindrical, striate when young, puberulous; hairs minute, patent to weakly curved, pale golden. Leaves congested at the terminal branches; internodes $2-10 \mathrm{~mm}$; stipules 2 per leaf node, persistent at least in younger leaves, 1.5-3 $\times$ $0.2-0.5 \mathrm{~mm}$, triangular, with a dark (glandular?) basal spot, the margins sometimes revolute; petiole to $1 \times$ $1.25 \mathrm{~mm}$, stout; leaf blade $1.6-9 \times 0.1-0.2 \mathrm{~cm}$ (rolled), chartaceous, linear or aciculate, apex pungent, base truncate, margins entire, strongly revolute and hiding nearly all the abaxial surface except for the midvein; adaxial surface puberulous when young, glabrescent with age, the midvein sulcate; abaxial surface puberulous, the midvein prominent; secondary veins inconspicuous on both surfaces. Panicles thyrsoid, terminal or subterminal at the distal leaf axils, narrow, isolated or in clusters of 2 or more; main axis $6.5-13 \mathrm{~cm}$, lateral axes to $8.5 \mathrm{~mm}$, cymules 1 - to 3 -flowered, shortly pedunculate, peduncles to $5 \mathrm{~mm}$; bracts congested at bases of major axes, or isolated at bases of cymules, $2.25-3 \times 0.5-0.8 \mathrm{~mm}$, triangular, 

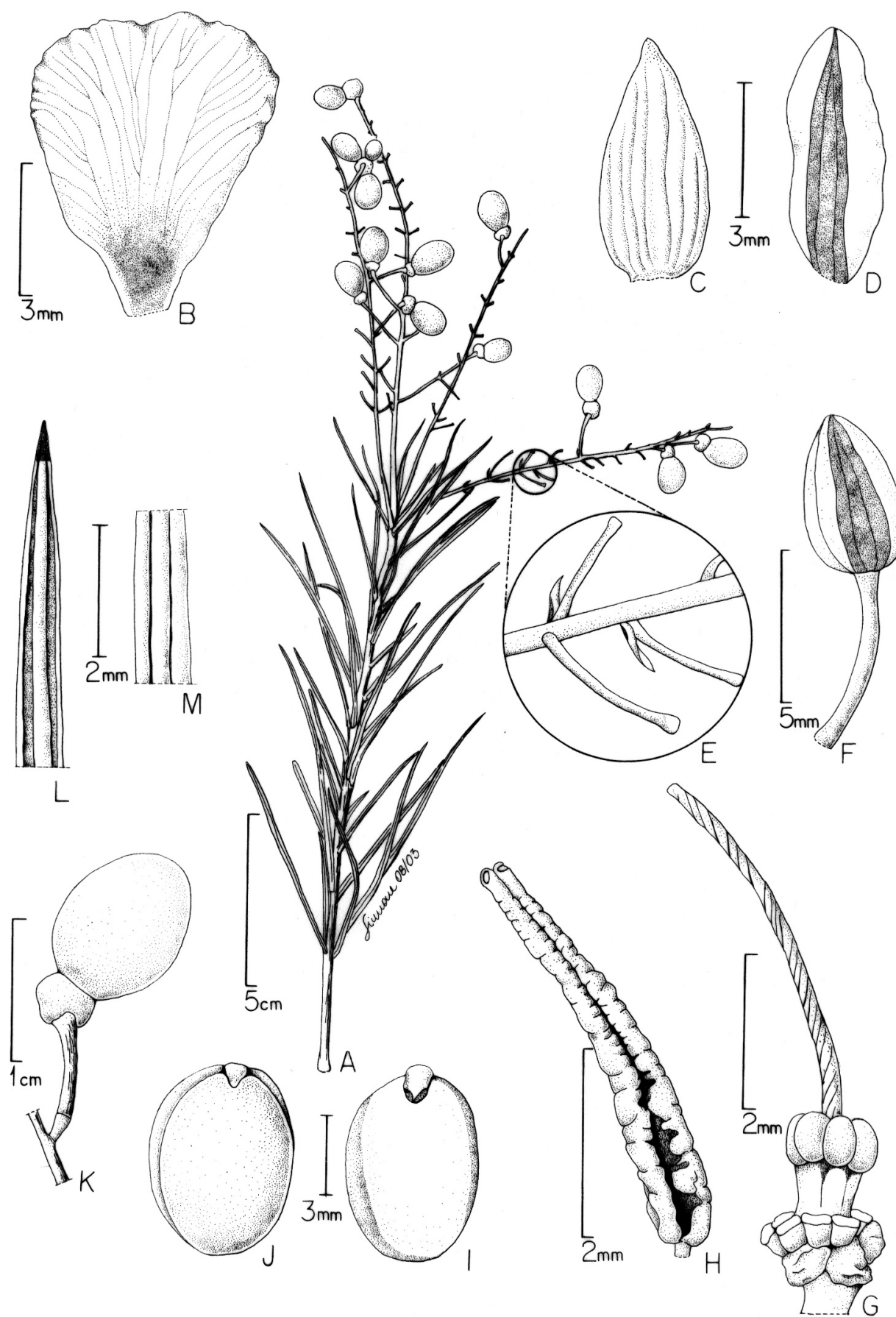

Figure 1. Ouratea acicularis R. Chacon \& K. Yamamoto. —A. Habit. —B. Petal. —C. Internal sepal. —D. External sepal. -E. Bracts. -F. Flower bud. -G. Gynoecium. - H. Stamen. -I. Inner view of cotyledon. -J. Embryo. —K. Fruit. -L. Abaxial leaf surface. - M. Detail of abaxial leaf surface. A, I-M from Ratter et al. 8115 (UB); B-H from Cavalcanti et al. 2757 (CEN). 


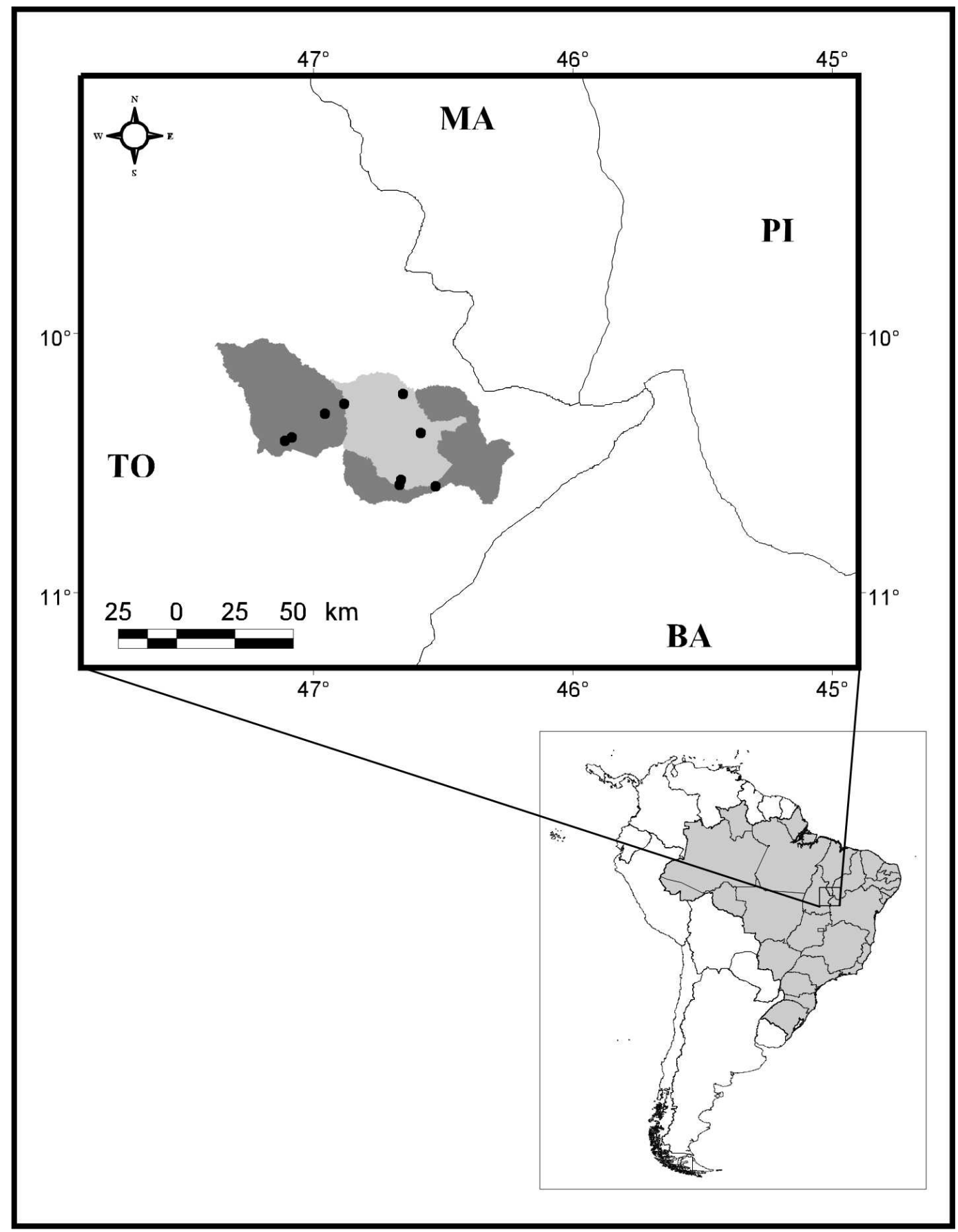

Figure 2. Geographic distribution of Ouratea acicularis R. Chacon \& K. Yamamoto. Dark gray shading denotes Estação Ecológica Serra Geral do Tocantins; light gray shading denotes Parque Estadual do Jalapão. BA = Bahia, MA = Maranhão, PI $=$ Piauí, TO = Tocantins. 
concave, striate, acute; bracteoles to $1.5 \times 0.5 \mathrm{~mm}$, linear, isolated or in pairs, persistent; pedicel 6$8.5 \mathrm{~mm}$, straight, puberulous, regularly slender in bud and flower, broadened at the base of the carpophore to $0.7-1 \mathrm{~mm}$ in ripe fruit. Flower bud 4-5 × 2.5-3 mm, ovoid, apex acute, base obtuse, puberulous; sepals 5 , ca. $6 \times 3 \mathrm{~mm}$, ovate, abaxial surface puberulous, early caducous; petals 5, 6-8.5 × 4.5-5 mm, yellow, obovate to orbicular-flabellate, asymmetric, base unguiculate; stamens 10, straight, anthers subsessile, ca. $5 \times$ $0.5 \mathrm{~mm}$, subulate, transversely rugulose, poricidal; gynoecium superior, 5-carpellate, the columnar gynophore $0.5-1 \mathrm{~mm}$, cylindrical to pentagonal near apex, fertile units 5, oblong, 0.5-1 × 1.1-1.2 mm; style ca. $4 \mathrm{~mm}$, filiform; stigma punctiform, yellow. Carpophore 2.5-5 $\times 4-7 \mathrm{~mm}$, salmon pink in the ripe fruit, mostly with a narrow and frequently curled basal portion expanding rather abruptly to a pyriform head; mericarps 1 or 2, erect or obliquely disposed on carpophore head, inflated, 1.1-1.6 × $0.7-1.2 \mathrm{~cm}$, ellipsoid, opaque; pericarp thin; seed ca. $0.5 \times 0.3 \mathrm{~cm}$, testa membranaceous, slightly rugose, embryo ellipsoid, cotyledons plano-convex, hypocotyl strap-shaped, perpendicular to the cotyledon.

Distribution, ecology, and phenology. Ouratea acicularis is apparently a narrow endemic of the Jalapão region in the state of Tocantins, Brazil, growing between 400 and 500 m.s.m. (Fig. 2). It was collected in rocky or sandy-soiled cerrado, i.e., grassy fields with scattered low trees and shrubs to $2 \mathrm{~m}$ tall. Flowers have been collected in May and June, and immature fruits in June and November.

IUCN Red List category. Ouratea acicularis is a narrow endemic occurring in specialized habitats of the Jalapão region, with a geographic distribution estimated as less than $7000 \mathrm{~km}^{2}$ and populations known to exist as no more than 10 isolated mature individuals. Based on this information and following IUCN Red List categories and criteria (IUCN, 2001), this species is assessed as Vulnerable (VU). However, it should be mentioned that all populations found are within the Estação Ecológica Serra Geral do Tocantins.

Discussion. Anatomical stem and leaf features that have not yet been recorded in the genus Ouratea, or in the family Ochnaceae, were found in $O$. acicularis. The anatomical characters of the new species were compared with O. miersii (Planchon) Engler, O. multiflora (Pohl) Engler, and O. parviflora Engler, based on a study by Yamamoto (1995). Because the anatomical characters of $O$. acicularis appear to be useful in distinguishing it from these congeneric species, the most outstanding of these features are described in Table 1.

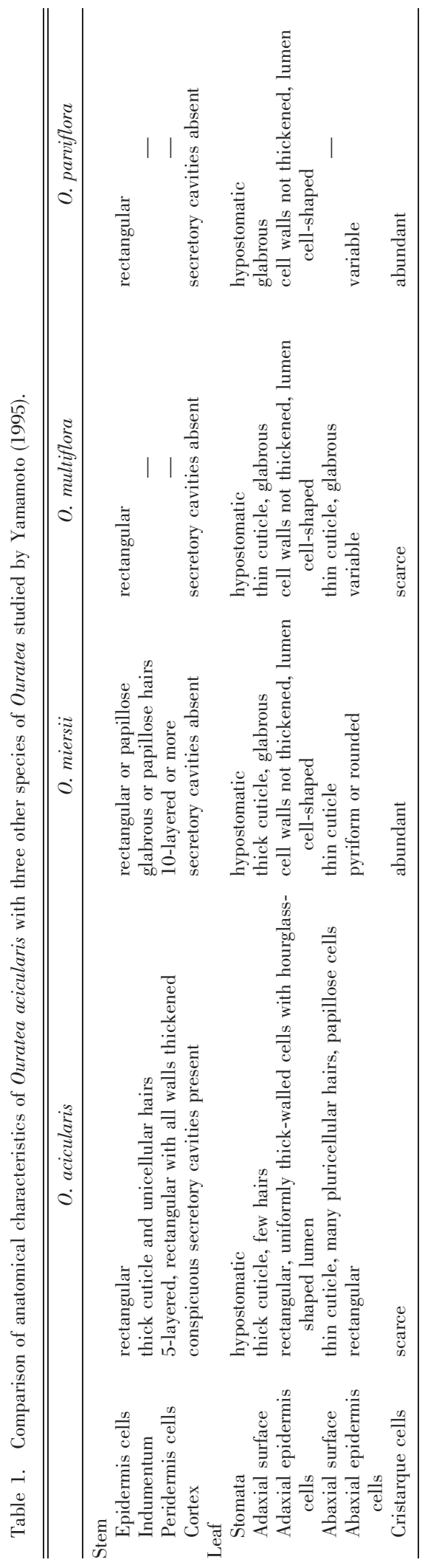



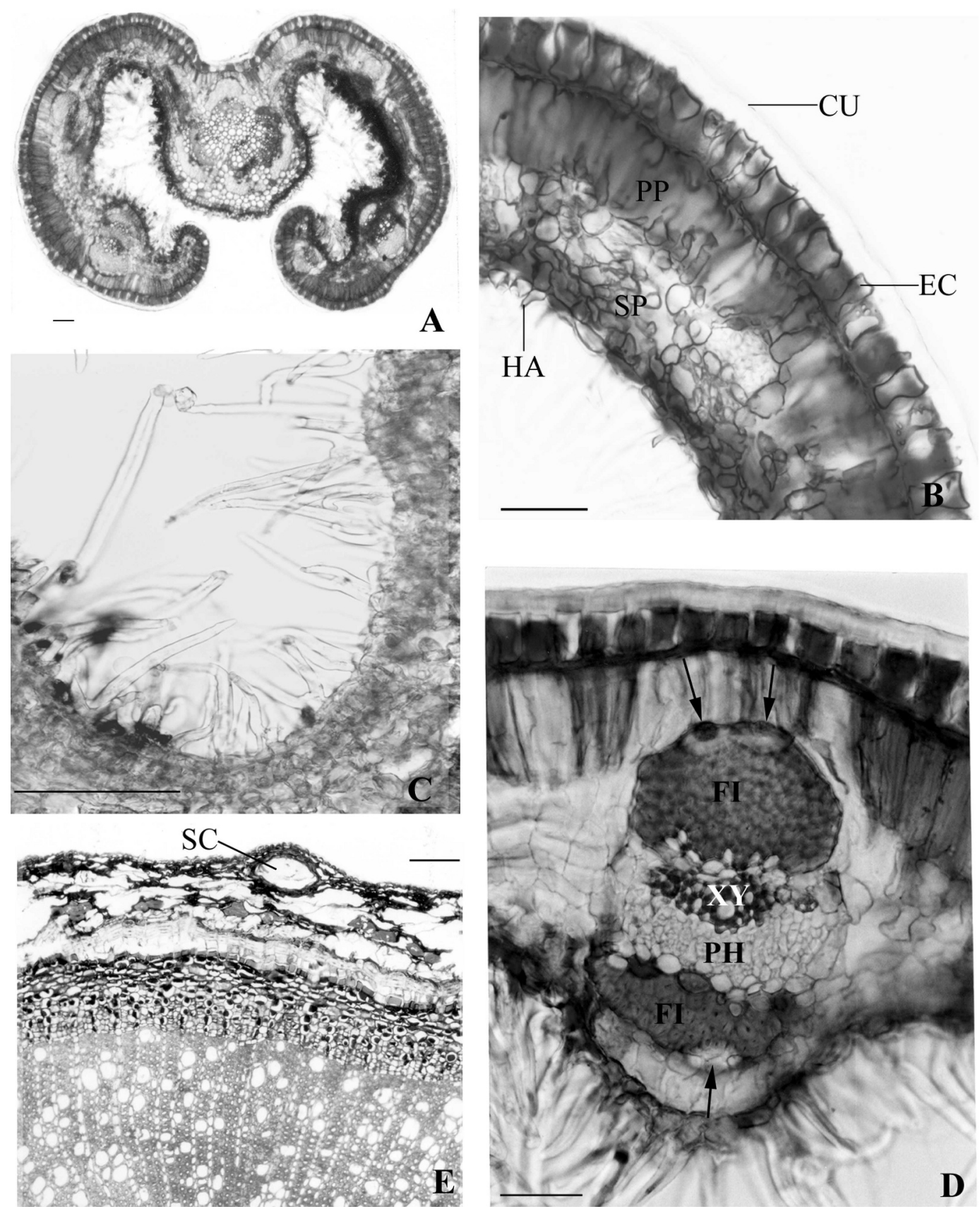

Figure 3. Leaf and stem anatomy of Ouratea acicularis R. Chacon \& K. Yamamoto. - A. Cross section of leaf. -B. Detail of leaf cross section. - C. Abaxial leaf surface showing pluricellular forked hairs. - D. Cross section of vascular bundles. - E. Cross section of stem secondary growth. $\mathrm{CU}=$ cuticle, $\mathrm{EC}=$ epidermal cells, $\mathrm{FI}=$ fibers, $\mathrm{HA}=$ hairs, $\mathrm{PH}=$ phloem, $\mathrm{PP}=$ palisade parenchyma, $\mathrm{SC}=$ secretory cavities, $\mathrm{SP}=$ spongy parenchyma, $\mathrm{XY}=$ xylem. Arrows signify cristarque cells. Scale bars $=50 \mu \mathrm{m}$.

Ouratea acicularis also appears to be anatomically unique in the genus (Fig. 3). Although the leaves of this species are hypostomatic with paracytic stomata, as is common in Ouratea, $O$. acicularis has the adaxial epidermis composed of cells with an hourglass-shaped lumen, here described for the first time in the genus, as well as the leaf indumentum with pluricellular forked hairs fused at the base. Until now, only unicellular 
Table 2. Morphological comparison of similarities and differences between Ouratea acicularis and O. oleifolia.

\begin{tabular}{|c|c|c|}
\hline & O. acicularis & O. oleifolia \\
\hline Leaf blade shape & $\begin{array}{l}\text { ca. } 1.6-9 \times 0.1-0.2 \mathrm{~cm}(\text { rolled); margins } \\
\text { entire, revolute }(\text { only the midvein } \\
\text { uncovered) }\end{array}$ & $\begin{array}{l}\text { ca. } 5-8 \times 1-2.5 \mathrm{~cm} \text {; margins entire, revolute (almost all } \\
\text { the abaxial surface uncovered) }\end{array}$ \\
\hline Lateral leaf veins & immersed, inconspicuous & $\begin{array}{l}\text { immersed, the secondary ones sharply discernible, the } \\
\text { intersecondary veins inconspicuous }\end{array}$ \\
\hline Indumentum & $\begin{array}{l}\text { puberulous, covering the young branches, } \\
\text { the midvein on both faces, the } \\
\text { inflorescence axes and the flower bud } \\
\text { (lower surface of the sepals) }\end{array}$ & $\begin{array}{l}\text { puberulous, covering the young branches, the inflorescence } \\
\text { axes and the flower bud (lower surface of the sepals), } \\
\text { and subvelutinous indument covering both leaf blade } \\
\text { surfaces, mostly the abaxial one }\end{array}$ \\
\hline Internode & $2-10 \mathrm{~mm}$ long & $\geq 7 \mathrm{~mm}$ long at distal nodes; leaves usually sparser basally \\
\hline Flower bud & $\begin{array}{l}4-5 \times 2.5-3 \mathrm{~mm} \text {, ovoid, apex acute, base } \\
\text { obtuse, puberulous }\end{array}$ & 4-6 $63-5 \mathrm{~mm}$, ovoid, apex acute, base obtuse, puberulous \\
\hline Habitat & $\begin{array}{l}\text { rocky cerrados or grassy fields with } \\
\text { scattered low trees and shrubs to } 2 \mathrm{~m} \\
\text { tall on red sandy soil }\end{array}$ & $\begin{array}{l}\text { savannas or similar sclerophyllous vegetation with small } \\
\text { trees on sandy soil }\end{array}$ \\
\hline Distribution & $\begin{array}{l}\text { state of Tocantins, apparently endemic to } \\
\text { the Jalapão region }\end{array}$ & $\begin{array}{l}\text { states of Bahia, Goiás, Minas Gerais, Pernambuco, and } \\
\text { Tocantins }\end{array}$ \\
\hline
\end{tabular}

hairs fused at the base and free pluricellular hairs had been described in Ouratea (see Solereder, 1908). The high degree of development of the cap of fibers and sclereids above the collateral vascular bundles is also unsurpassed in the genus. The most noteworthy anatomical novelty found in $O$. acicularis is the conspicuous secretory cavities in the stem cortex. The secondary xylem axial system is also outstanding due to the dominance of fibers and vessel members, with hardly any parenchyma. Unfortunately, O. oleifolia, which seems to be the most morphologically similar species, has not been studied anatomically.

The acicular leaf blade of Ouratea acicularis has margins so strongly revolute that they conceal the abaxial surface, leaving only the midrib uncovered (Figs. 1, 3); this kind of leaf is apparently unique to this species within the genus Ouratea. Most species of Ouratea have elliptic, oblong, ovate, cordate, or obovate leaves with regularly flattened surfaces and only rarely revolute margins, which never conceal the entire abaxial leaf surface. Also, on the adaxial surface the lateral veins are immersed and inconspicuous in $O$. acicularis, while in most species of Ouratea the lateral veins are clearly visible, especially the secondary ones that are characteristically curved upward, with most ending at the margins or occasionally forming anastomosing loops (see descriptions in Engler, 1876; Maguire \& Steyermark, 1989).

Morphological, ecological, and geographical similarities suggest that Ouratea acicularis belongs to the taxon O. oleifolia sensu Engler (1876) and is most closely related to that species. Ouratea oleifolia is distributed in the more arid savannas of northern Minas Gerais and Bahia to Pernambuco, Piauí, and eastern Tocantins (former Goiás); this distribution area is much wider than but overlaps with that of $O$. acicularis. Thus, ecological and geographical features corroborate the relationship that morphological characters suggest between $O$. acicularis and O. oleifolia.

Although the wide circumscription of Ouratea oleifolia proposed by Engler (1876) is adopted in this paper, this is not a consensus, as Engler's circumscription was rejected by Tieghem (1902). Engler (1876) united several taxa that are treated as distinct by previous or later taxonomists as varieties of $O$. oleifolia based on slight differences in indumentum density (Tieghem, 1902).

Regardless of the classification accepted for this complex, Ouratea acicularis is sharply distinct from O. oleifolia sensu Engler (1876) by its linear-aciculate leaf blade that is at least four times narrower than in $O$. oleifolia, with a strongly revolute margin that conceals the abaxial leaf surface except for the midrib, and inconspicuous secondary venation on the adaxial surface, as well as by its narrower flower buds (see Table 2 for a detailed comparison).

Paratypes. BRAZIL. Tocantins: Mun. Mateiros, $10^{\circ} 24^{\prime} \mathrm{S}$, $47^{\circ} 05^{\prime}$ W, R. Farias, J. Fonsêca Filho, S. Bridgewater \& J. A. Ratter 157 (UB); Mun. Mateiros, Dunas, $10^{\circ} 35^{\prime} \mathrm{S}, 46^{\circ} 40^{\prime} \mathrm{W}, A$. B. Sampaio, P. L. Simpson Jr., R. Farias \& L. C. Milhomens 545 (UB); $15 \mathrm{~km}$ from Mateiros on rd. Mateiros-Ponte Alta, $10^{\circ} 35^{\prime} 19^{\prime \prime} \mathrm{S}, 46^{\circ} 31^{\prime} 42^{\prime \prime} \mathrm{W}$, T. B. Cavalcanti, A. O. Scariot, A. C. Sevilha, G. Pereira-Silva \& A. B. Sampaio 2757 (CEN, UEC).

Acknowledgments. The authors thank Simone Sousa e Silva for the illustration, Moacir Arruda and Miguel von Behr (IBAMA) for organizing the 2001 Jalapão scientific expedition and for their great dedication to conservation in the region, S. A. Harris for commenting on the manuscript, and C. Sastre for helpful suggestions that improved the final manu- 
script. We are indebted to the Conservação e Manejo da Biodiversidade do Bioma Cerrado Project (Department for International Development/Empresa Brasileira de Pesquisa Agropecuária [Embrapa]/IBAMA), Embrapa Recursos Genéticos e Biotecnologia, PEQUI-Pesquisa e Conservação em Cerrado, and Conservation International Brazil for financial and logistical support for fieldwork.

\section{Literature Cited}

Arruda, M. B. \& M. von Behr. 2002. Introdução. Pp. 11-12 in M. B. Arruda \& M. von Behr (editors), Jalapão: Expedição Científica e Conservacionista. IBAMA, Brasília.

Barroso, G. M., M. P. Morin, A. L. Peixoto \& C. L. F. Ichaso. 1999. Frutos e Sementes. Morfologia Aplicada à Sistemáticas de Dicotiledôneas. Universidade Federal de Viçosa, Minas Gerais, Brazil.

Baum, H. 1951. Die Frucht von Ochna multiflora DC., ein Fall ökologischer Apokarpie. Oesterr. Bot. Z. 98(4): 388-395.

Engler, A. 1876. Ochnaceae. Pp. 301-332, pl. 62-77 in C. F. P. Martius \& I. Urban (editors), Flora Brasiliensis $12(2)$.

Guédès, M. \& C. Sastre. 1981. Morphology of the gynoecium and systematic position of the Ochnaceae. Bot. J. Linn. Soc. 82: 121-138.

IUCN. 2001. IUCN Red List Categories and Criteria Version 3.1. Prepared by the IUCN Species Survival Commission. IUCN, Gland, Switzerland, and Cambridge, United Kingdom.

Maguire, B. \& J. A. Steyermark. 1989. Ouratea (Ochnaceae) in Guyana and adjacent Amazonian hylea. Mem. New York Bot. Gard. 51: 56-102.

Mittermeier, R. A., N. Myers, P. R. Gil \& C. G. Mittermeier. 1999. Hotspots: Earth's Biologically Richest and Most Endangered Terrestrial Ecoregions. Conservation International, Arlington, Virginia, and CEMEX, Houston.
Proença, C. E. B., A. B. Sampaio, L. C. Milhomens, L. H. Soares e Silva, M. F. Simon, P. L. Simpson Jr. \& R. Farias. 2002. Relatório da botânica. Pp. 21-28 in M. B. Arruda \& M. von Behr (editors), Jalapão: Expedição Científica e Conservacionista. IBAMA, Brasília.

- , R. F. Singer \& B. M. Gomes. 2007. Pleonotoma orientalis (Bignonieae, Bignoniaceae): Expanded description, distribution, and a new variety of a poorly known species. Edinburgh J. Bot. 64: 17-23.

Reis, M. L., D. C. Coelho, D. de F. Pereira, I. H. Carvalho, M. L. de A. Nunes, M. F. Simon \& V. da S. Braz. 2002. Relatório da zoologia. Pp. 29-44 in M. B. Arruda \& M. von Behr (editors), Jalapão: Expedição Científica e Conservacionista. IBAMA, Brasília.

Sastre, C. 1988. Studies on the Flora of the Guianas 34 . Synopsis generis Ouratea Aublet (Ochnaceae). Bull. Mus. Natl. Hist. Nat., B, Adansonia 1: 47-67.

- 2001. New Ouratea species (Ochnaceae) from Venezuela and adjacent countries. Novon 11: 105-118.

Scariot, A. O., T. B. Cavalcanti, A. C. Sevilha, A. B. Sampaio, M. Carvalho-Silva \& G. Pereira-Silva. 2002. Flora e Vegetação do Entorno do Parque Estadual do Jalapão (TO): Relatório de Atividades. EMBRAPA, Brasília.

Solereder, H. 1908. Systematic Anatomy of the Dicotyledons. Clarendon Press, Oxford.

Spujt, R. W. 1994. A systematic treatment of fruit types. Mem. New York Bot. Gard. 70: 1-182.

Tieghem, P. van. 1902. Sur les Ochnacées. Ann. Sci. Nat., Bot. 16: 161-416.

Whitefoord, C. 1992. Eight new species of Ouratea (Ochnaceae) from Mesoamerica. Novon 2: 274-281.

Yamamoto, K. 1989. Morfologia, Anatomia e Sistemática do Gênero Ouratea Aubl.: Levantamento Preliminar de Características de Importância Taxonômica e Avaliação das Classificações Vigentes. Dissertação de Mestrado, Programa de Pós Graduação em Biologia Vegetal, Universidade Estadual de Campinas, Campinas, Brasil.

. 1995. Estudos Taxonômicos Sobre Ouratea parviflora (DC.) Baill. (Ochnaceae) e Espécies Afins Ocorrentes em Floresta Atlântica nas Regiões Sudeste e Sul do Brasil. Ph.D. Thesis (unpubl.), Universidade Estadual de Campinas, Brazil. 